\title{
TRANSMISI IDEOLOGI FUNDAMENTALISME DALAM PENDIDIKAN
}

\author{
Husnatul Mahmudah \\ Dosen Fakultas Syariah IAI Muhammadiyah Bima \\ arraynez@gmail.com
}

\begin{abstract}
Abstrak
Tulisan ini berusaha menguraikan tentang transmisi ideologi fundamentalisme dalam pendidikan. Eskpansi gerakan keagamaan transnasional membawa serta ideologi fundamentalisme yang melekat padanya. Gerakan keagamaan ini memandang Islam sebagai ideologi dan politik. Karena itu, fundamentalisme merupakan konsekuensi logis penempatan syariat sebagai referensi utama gerakan Islam. Pandangan tentang keterancaman masa depan Islam akibat gencarnya serangan globalisasi kemudian menjadi titik dasar untuk memperjuangkan Islam lewat berbagai bidang kehidupan. Modernisasi pendidikan Islam seiring dengan pertumbuhan kelas menengah Muslim perkotaan di Indonesia, juga diikuti oleh fenomena maraknya sekolah Islam terpadu. Degradasi moral bangsa dan kualitas pendidikan nasional yang masih jauh dari harapan masyarakat semakin menambah kegelisahan masyarakat kelas menengah terhadap masa depan dan kualitas pendidikan anak-anak mereka. Menjawab kegelisahan tersebut, berbagai gerakan keagamaan mengambil peran untuk memberikan solusi praktis dalam bidang pendidikan Islam. Kelompok fundamentalis ini membingkai serta mentransmisikan ideologi fundamentalisme dalam pendidikan dengan menggunakan pola eksklusif protektif. Pola ini dikembangkan untuk menginternalisasikan paham dan nilai-nilai yang dianggap benar sekaligus memproteksi paham dan nilai lain yang datang dari luar. Transmisi idelogi tersebut dilakukan lewat proses kegiatan belajar mengajar yang didalamnya memuat hidden curriculum yang bertentangan dengan unsur-unsur peace education.
\end{abstract}

Kata Kunci: Transmisi, Fundamentalisme, Pendidikan.

\section{Pendahuluan}

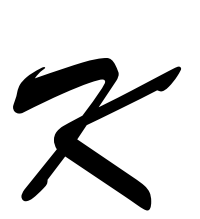

onflik dan krisis yang diakibatkan oleh kebekuan masyarakat dalam menafsirkan agama dan ideologi telah menjadi fakta yang tidak terbantahkan dewasa ini. Gerakan radikalisme sebagaimana dalam berbagai kasus kerusuhan di Sambas, Ambon, Poso dan munculnya kasus terorisme dengan dalih jihad atas nama Islam, tidak lepas dari tafsir masyarakat atas agama dan ideologi yang mengitarinya.

Menyikapi munculnya berbagai kasus kekerasan atas nama agama di berbagai daerah tersebut, oleh para analis sosial politik menitikberatkan pada ketimpangan sosial ekonomi sebagai akar konflik. Sangat sedikit yang menyadari bahwa kekerasan-kekerasan itu disebabkan oleh model pendidikan yang diterapkan oleh institusi-institusi agama dan ideologi tertentu. Ideologi yang mendasari penyelenggaraan pendidikan akan menentukan kemana pendidikan akan diarahkan, sekaligus untuk menempatkan di mana sebenarnya posisi pendidikan akan berdiri, apakah berujung pada ekstrim, fundamentalis, rasional atau pada titik pertengahan yakni berada antara liberal dan konservatisme. 
Pilihan ideologi menjadi sangat penting karena akan menjadi penuntun di masa sekarang dan mendatang terhadap pilihan konseptual sebuah penyelenggaraan pendidikan. Di Indonesia pada awalanya mengenal ideologi tunggal yakni Pancasila, namun sekarang berkembang ideologi lain, yakni "agama" yang menjadi pilihan penyelenggara pendidikan, disamping partai politik. ${ }^{1}$

Menurut Zuly Qodir, pilihan paradigma ideologi dalam penyelenggaraan pendidikan juga akan berpengaruh pada persoalan mendasar pendidikan tersebut dilaksanakan. Pertama, untuk siapa atau kelompok sasaran yang mana, sehingga akan jelas bahwa pilihan paradigma akan menentukan banyak konsekuensi dibelakangnya tatkala telah ditentukan oleh sebuah instrumen politik tertentu. Kedua, pendidikan untuk apa, sehingga akan menentukan isi kurikulum dan materi seperti apa yang akan diajarkan. Ketiga, bagaimana pelaksanaan pendidikan akan dikerjakan. Hal ini akan menyangkut tentang pola organisasi pendidikan itu sendiri, pilihan bentuk pedagoginya dan instrumen-instrumen lainnya, termasuk bagaimana peran serta masyarakat di luar penyelenggara pendidikan dalam bangunan pendidikan yang hendak dikerjakan. ${ }^{2}$

Pendidikan merupakan sarana yang cukup efektif dalam mensosialisasikan doktrin dan nilai yang dipandang ideal. Oleh sebab itu, banyak pihak yang memilih jalan pendidikan untuk melestarikan ideologinya demi tercapai tujuan akhir yang diharapkan. Tidak menutup kemungkinan pula oleh kelompok fundamentalis Islam. Kelompok fundamentalis penyelenggara pendidikan yang dimaksud dalam tulisan ini adalah dari kelompok salafi, PKS dan Hidayatullah. ${ }^{3}$ Kelompok ini merupakan gerakan transnasional yang memiliki ideologi dan visi gerakan yang hampir sama, yaitu berupaya mengIslamkan dan membentuk masyarakat Islam sejati dari bawah, dengan menciptakan tatanan Islam yang baru lewat berbagai bidang.

Maraknya sekolah Islam Terpadu yang dikembangkan oleh beberapa kelompok fundamentalis menunjukan bahwa mereka juga melirik pendidikan sebagai sarana untuk mentransmisi ideologi. Dengan menitikberatkan pada doktrin keagamaan dan menyampingkan semangat nasionalisme kebangsaan, kelompok-kelompok ini hadir dengan warna yang berbeda dari penyelenggara pendidikan pada umumnya.

Dalam proses pengajaran, aspek yang diutamakan adalah aspek hukum agama dan akidah, yang notabene sangat rentan dengan eksklusifisme dan fundamentalisme. Padahal, pendidikan adalah aspek terpenting dalam membentuk kepribadian bangsa. Apa jadinya bila

${ }^{1}$ Lihat Paulo Freire dkk, Menggugat Pendidikan; Fundamentalisme, Konservatif, Liberal, Anarkis (Yogyakarta: Pustaka Pelajar, 2001).

${ }^{2}$ Zuly Qodir, Gerakan Sosial Islam: Manivesto Kaum Beriman (Yogyakarta: Pustaka Pelajar, 2009), 295.

${ }^{3}$ Menurut Noorhaidi Hasan, ketiga kelompok yang disebutkan diatas adalah salafi. Namun mereka saling memisahkan diri karena beberapa perbedaan. Perbedaan yang paling menonjol adalah dalam menerima dan menolak system demokrasi. Selengkapnya lihat Noorhaidi Hasan, Laskar Jihad: Islam, Militansi dan Pencarian Identitas di Indonesia Pasca-Orde Baru, (Jakarta: LP3ES, 2008). 
pendidikan dikotori oleh fundamentalisme dan semangat-semangat kelompok yang lambat laun akan membentuk kepribadian bangsa yang puritan dan eksklusif. ${ }^{4}$

Anak didik diajarkan untuk memprioritaskan percaya pada doktrin agama, tanpa harus mempertanyakannya. Dalam ajaran agama diajarkan yang namanya truth claim, yaitu percaya bahwa agama hanya ada satu agama yang paling benar, kemudian diajarkan ritualritual keberagamaan yang indikatornya tidak hanya mengarah pada aspek kognitif, namun juga psikomotorik, sehingga anak didik tidak cukup menjadikannya sebagai pengetahuan, namun juga harus bisa mempraktekkannya. ${ }^{5}$

Kurikulum semacam itu selain membunuh daya kritis anak didik, juga seakan-akan bertujuan untuk mengutamakan keberagamaan dan meletakkan kepentingan kewarganegaraan pada ranah sekunder. Hal ini sangat bertentangan dengan tujuan utama kewarganegaraan dan realitas kemajemukan Indonesia. Sehingga output dari proses pendidikan semacam itu tidak bisa diharapkan untuk bersikap adil dan bijak ketika dihadapkan dalam realitas kemajemukan di Indonesia.

Hal ini sangat bertentangan dengan prinsip peace education, atau dapat dikatakan sebagai anti-peace education. Peace education ialah sebuah proses untuk mendapatkan pengetahuan, pengembangan sikap, dan tingkah laku untuk hidup dalam keharmonisan dengan orang lain. Peace education merupakan model pendidikan yang mengupayakan pemberdayaan masyarakat agar mampu mengatasi konflik atau masalahnya sendiri dengan cara kreatif dan bukan dengan cara kekerasan. Secara esensial, peace education ialah pendidikan yang mengajarkan rasa saling menghargai, mencintai, fairness, dan keadilan. ${ }^{6}$ Sehingga sebagai salah satu upaya untuk resolusi konflik, peace education (pendidikan perdamaian) dipandang perlu untuk meminimalisir akar kekerasan dan konflik sedini mungkin.

Pendidikan perdamaian perlu dilakukan untuk menciptakan perdamaian, karena focus utama pendidikan perdamaian adalah merubah perilaku (focus on behavioural change), hal ini dapat terbaca pada definisi pendidikan perdamain yang dirujuk UNICEF. Definisi tersebut menyatakan bahwa pendidikan perdamaian merupakan proses pemajuan pengetahuan (knowledge), kecakapan-kecakapan (skill), sikap-sikap (attitudes), dan nilai-nilai (values) yang dibutuhkan untuk menghasilkan perubahan tingkah laku yang mana akan memungkinkan anak-anak, remaja, dan dewasa untuk: (1) mencegah konflik dan kekerasan, baik tindakan maupun secara struktural (to prevent conflict and violence, both overt and structural); (2) memecahkan konflik secara damai (to resolve conflict peacefully); dan (3) menciptakan kondisi yang kondusif bagi perdamaian (to create the conditions conducive to

\footnotetext{
${ }^{4}$ Zuly Qodir, Sosiologi Agama, (Yogyakarta: Pustaka Pelajar, 2011), 75.

${ }^{5}$ Zakiyuddin Baidhawy, Pendidikan Agama Berwawasan Multikultural (Jakarta: Erlangga, 2005), 8.

${ }^{6}$ Susan Fountain, Peace Education in UNICEF, UNICEF Staff Working Papers Programme Division UNICEF, New York 1999, 2.
} 
peace), apakah pada level diri individu (intrapersonal), antarindividu (interpersonal), dalam kelompok (intergroup), national (national) atau internasional (international). ${ }^{7}$

Secara implisit Undang-Undang Sistem Pendidikan Nasional juga mengandung amanat, yaitu pendidikan tidak hanya bermanfaat dalam satu waktu akan tetapi harus sejalan dengan tuntutan zaman.

"Pendidikan nasional adalah pendidikan yang berdasarkan Pancasila dan UndangUndang Dasar Negara Republik Indonesia Tahun 1945 yang berakar pada nilai-nilai agama, kebudayaan nasional Indonesia dan tanggap terhadap tuntutan perubahan zaman."

Oleh sebab itu pendidikan diyakini sebagai jalan keluar terbaik untuk mengatasi berbagai permasalahan sosial dan perbaikan kondisi bangsa yang telah rapuh. Dalam konteks pendidikan, semua persoalan dalam masyarakat akan dapat diperbaiki melalui proses pendidikan. Artinya kegagalan masyarakat adalah kegagalan pendidikan, begitu pula sebaliknya.

Merujuk pada tujuan dan fungsi pendidikan di atas, kiranya tidak berlebihan jika mengatakan bahwa pendidikan di Indonesia masih jauh dari yang diharapkan. Hal ini terlihat dari maraknya kekerasan yang terjadi di berbagai wilayah Indonesia belakangan ini. Berdasarkan latar belakang tersebut di atas, penulis merasa perlu untuk mengkaji lebih jauh tentang pengaruh gerakan keagamaan dengan beragam ideology yang melekat padanya, serta upaya untuk melakukan transmisi ideology tersebut dalam dunia pendidikan.

\section{Ideologi Fundamentalisme: Perdebatan Merumuskan Definisi}

Sebuah ideologi bekerja mengikuti arus rasionalitas. Dalam pengertian ini, makna atau ide akan mempengaruhi konsepsi dan aktivitas individu maupun kelompok yang kemudian membentuk dunia sosial. Oleh karena itu, studi bahasa yang memiliki kekuatan memobilisir individu atau sebuah kelompok dalam dunia sosial, mendapatkan posisi istimewa. Ideologi sebagai sebuah sistem simbol juga memiliki korelasi yang kuat dengan tindakan sosial. Wacana permusuhan dan konfrontatif yang diusung oleh gerakan Islam "radikal" terhadap agama Kristen dan Yahudi misalnya, menjadi sebuah kekuatan tidak saja bagaimana kelompok ini memandang kedua agama tersebut. Namun juga bisa menjadi potensi laten yang sewaktu-waktu dapat memunculkan konflik dan kekerasan. ${ }^{9}$

Secara teoritik, ideologi menurut Noorhaidi Hasan, merupakan sistem keyakinan, gagasan, nilai, dan makna yang mencerminkan kepentingan moral, sosial dan politik, serta komitmen suatu kelompok tertentu. Berdasarkan ideologilah kelompok tersebut menciptakan

\footnotetext{
${ }^{7}$ Susan Fountain, Peace Education in UNICEF, 3.

${ }^{8}$ Lihat UU Nomor 20 Tahun 2003 tentang Sistem Pendidikan Nasional Pasal 1 Ayat 2

9 John B. Tompson, Analisis Ideologi: Kritik Wacana Ideologi-Ideologi Dunia, terj. Haqqul Yaqin,(Yogyakarta: IRCiSoD, 2003), 127-128.
} 
pemahaman bagaimana seharusnya dunia ini berjalan. ${ }^{10}$ Teun A. Van Dijk, sebagaimana dikutip oleh Noorhaidi mengemukakan bahwa sebagai sistem keyakinan, ideologi perlu dipahami dalam kerangka "segitiga", yakni kognisi sosial, masyarakat, dan wacana. Menurut pandangannya, ideologi tidak hanya merepresentasikan identitas dan kepentingan kelompok, tapi juga merumuskan kohesivitas kelompok dan mengatur aksi bersama dan interaksiinteraksi untuk mewujudkan tujuan-tujuan kelompok secara optimal. ${ }^{11}$ Ideologi demikian penting dalam sebuah gerakan, bahkan oleh sebagian pengamat menyatakan bahwa ideologi jauh lebih penting daripada framing (pembingkaian), karena ideologi dapat menyampaikan makna yang lebih dalam dan rumit. Ideologi menangkap keyakinan dan gagasan aktor dengan cara yang tidak bisa dilakukan oleh framing. ${ }^{12}$

Dengan demikian, ideologi menjadi sangat penting sebagai landasan untuk mengatur tindakan dan tujuan anggotanya agar lebih terarah dan optimal. Sehingga perlawanan yang berbasis ideologi akan sangat berbeda dengan gerakan perlawanan yang berbasis kelas, sebab perlawanan kelas akan berhenti ketika sebuah capaian ekonomi-politik telah didapatkan. Akan tetapi perlawanan berbasis ideologi akan terus mengelaborasi sisi-sisi ideologis dari apa yang diyakini sebagai sebuah kebenaran, yang secara terus-menerus di perjuangkan.

Sebelum membahas lebih jauh tentang fundamentalisme, perlu diberikan definisi yang diharapkan bisa membantu menjelaskan tentang fundamentalisme sehingga dapat menjadi guide line tentang masalah yang dibahas. Fundamentalisme memiliki pengertian berbedabeda, bahkan sering kabur dan sengaja dikaburkan makna sesungguhnya. Hal ini dikarenakan istilah fundamentalisme akan beriringan dengan realitas yang ada di sekelilingnya. Fundamentalisme merupakan sebuah istilah yang memiliki tafsir sangat longgar dan sangat sosiologis, tetapi tidak jarang menjadi tafsir yang idiologis dan teologis.

Pada mulanya istilah ini muncul dari bahasa Perancis yang berasal dari kata fonamental yang berarti dasar, yang menjadi pokok dan yang penting. ${ }^{13}$ Menurut Bassam Tibi, fundamentalisme adalah gejala ideologis yang muncul sebagai respon atas problem-problem globalisasi, fragmentasi dan benturan peradaban. ${ }^{14}$ Tibi menegaskan bahwa fundamentalisme merupakan ideologi politik yang lebih dekat dengan politisasi agama, ketimbang kepercayaan agama itu sendiri. Politisasi agama dalam rangka menegakkan kembali tujuan-tujuan sosio-ekonomi dan politik berdasarkan tatanan Tuhan. Bagi kaum fundamentalis agama adalah ekspresi tatanan Tuhan, demikian juga dunia, oleh karena itu dunia ini tidak bisa diatur menggunakan tatanan sekuler. ${ }^{15}$

${ }^{10}$ Noorhaidi Hasan, Islam Politik di Dunia Kontemporer, (Yogyakarta: Suka Press, 2012), 64.

${ }^{11}$ Ibid., 65.

${ }^{12}$ Ibid., 66.

${ }^{13}$ Pius A. Partanto, M. Dahlan al-Bary, Kamus Ilmiah Populer, (Surabaya: Arkola, 1994), 190.

${ }^{14}$ Bassam Tibi, Ancaman Fundamentalisme; Rajutan Islam Politik dan Kekacauan Dunia, (Yogyakarta: Tiara Wacana, 2000), 8.

${ }^{15}$ Bassam Tibi, Ancaman Fundamentalism........., 35-36. 
Fundamentalisme oleh Azyumardi Azra diklaim sebagai bentuk ekstrem dari gejala revivalisme, dalam perjalanannya yang demikian panjang, seringkali menimbulkan kesulitan untuk dibedakan secara rigid. Bahkan generalisasi yang distortif dan simplikatif sering terjadi, baik yang dilakukan oleh ilmuwan Barat maupun pemikir dan umat Islam sendiri. Fundamentalisme sebagai bentuk ekstrem dari segala revivalisme, tidak hanya meningkatkan intensifikasi keIslamannya yang lebih berorientasi ke dalam sebagaimana ditemukan dalam gejala revivalisme yang lebih bersifat individual, tetapi juga berorientasi ke luar yang difokuskan sebagai gerakan yang mengarah dan lebih bersifat komunal dan masif. Oleh karena itu, gejala revivalisme terindikasikan tidak hanya dalam peningkatan gejala esoterisme Islam, namun lebih menunjukan aspek eksoterisme yang sangat menekankan pada kebolehan dan ketidakbolehan atas sesuatu atau sejumlah perilaku, berdasarkan batas-batas fikih secara hitam putih. ${ }^{16}$

Perspektif yang berbeda tentang pengertian fundamentalisme dapat dilihat dalam pemikiran Mohammed Arkoun yang menyatakan bahwa fundamentalisme Islam sebenarnya bukanlah merupakan bagian dari Islam, tetapi merupakan fenomena sosial dan politik semata. Dikemukakan bahwa gerakan fundamentalisme Islam kontemporer ini bukan merupakan "Islam" dan harus dipisahkan dengan "Islam." Fundamentalisme tidak lebih merupakan hasil dari ideologisasi dan politisasi Islam. Demikian pula halnya keseluruhan faktor yang menggerakkan fundamentalisme Islam, baik oposisi, susunan ideologis, impian kolektif maupun halusinasi individual, tidaklah menuju kepada Islam sebagai agama dan tradisi pemikiran. ${ }^{17}$

Dengan demikian, fundamentalisme Islam sama halnya dengan fungsi dan kerja ideologi-ideologi besar lainnya dalam memanipulasi dan menggerakkan fantasi anggotanya. Tujuan yang ingin dikehendaki dan diraih dari para aktor dan mobilisator gerakan ini, menurut Mohammad Arkoun, bukanlah "Islam" itu sendiri, tetapi hal-hal lain diluarnya. Dapat dikemukakan bahwa pandangan Arkoun ini meneguhkan bahwa fundamentalisme Islam kontemporer sejatinya merupakan gerakan-gerakan politis dan ideologis biasa, dan bukanlah gerakan Islam. Namun sayangnya kerancuan ini menurut Arkoun, telah diperparah oleh berbagai kekeliruan banyak orientalis Barat yang meletakkan para fundamentalis sebagai “juru bicara” Islam, yang akhirnya memberikan gambaran negatif dan merusak Islam serta orang-orang Muslim kontemporer. ${ }^{18}$

Pada akhirnya, ditengah kerancuan makna dari istilah Fundamentalisme ini, penulis menyimpulkan bahwa fundamentalisme adalah bentuk ekstrem dari revivalisme, yang secara teologis merupakan gerakan yang identik dengan literalisme, konservatif, cenderung

16 Azyumardi Azra, Pergolakan Politik Islam: dari Fundamentalisme, Modernisme, hingga PostModernisme, (Jakarta: Paramadina, 1996), 107.

${ }^{17}$ Mohammed Arkoun, membongkar Wacana Hegemonik dalam Islam dan Postmodernisme, (Surabaya: Alfikr, 1999), 209.

${ }^{18}$ Ibid., 210-211. 
menolak modernisme. Muncul sebagai ideologi yang merespon problem globalisasi dan benturan antar peradaban. Sehingga fundamentalisme dapat juga dikatakan sebagai hasil ideologisasi dan politisasi Islam.

\section{Transmisi Ideologi Fundamentalisme dan Proses Pencarian Keautentikan}

Pada umumnya, gerakan-gerakan Islam baik yang tradisional maupun modernis, menurut Manfred Ziemek, muncul sebelum proklamasi kemerdekaan Indonesia, yaitu pada periode antara 1900-1940-an. Meskipun demikian, akar gerakannya khususnya Islam tradisional, telah tumbuh jauh sebelum periode tersebut. Akar-akar gerakan Islam tradisional mulai bersemi sekurang-kurangnya bersamaan dengan masuk dan semakin meluasnya pemelukan Islam di pedalaman Jawa pada saat Islam mulai mengalami proses menyerap dan diserap oleh unsur-unsur budaya lokal. Proses yang lazim pula disebut sebagai "domestikasi Islam"19 itu berlangsung sekitar abad ke-16 dan ke-17 Masehi, dimana aspek-aspek mistik dari ajaran Islam (tasawuf) menunjukan pengaruh yang kuat. ${ }^{20}$

Transmisi gerakan transnasional dalam kehidupan masyarakat nusantara telah berlangsung sejak sebelumnya yang ditandai dengan masuknya pengaruh ideologi keagamaan Timur Tengah ${ }^{21}$ melalui jaringan ulama. ${ }^{22}$ Berdirinya Sarekat Islam (1912), Muhammadiyah (1912), dan Persatuan Islam (1923), tidak dapat dilepaskan dari pengaruhpengaruh ideologi Timur Tengah. Jaringan ulama nusantara dengan ulama-ulama Timur

${ }^{19}$ Domestikasi Islam adalah penjinakan agama atas negara. Namun pertarungan kekuasaan agama dan negara terlihat jelas pada abad ke-16 dan 18. Perebutan kekuasaan antara kerajaan-kerajaan Islam taat di wilayah pesisir Jawa yang diwakili oleh Demak melawan kerajaan Mataram yang terkenal sinkretis dan terletak di pedalaman. Ketika kerajaan terakhir ini memeluk Islam, ia berusaha menekankan dominasi kuat atas wwilayah pesisir yang kerap memberontak. Penaklukan Mataram atas wilayah pesisir inilah yang dikenal dengan istilah domestikasi Islam. Harry J. Benda, Kontinuitas dan Perubahan dalam Islam di Indonesia, dalam Taufik Abdullah (ed), Islam di Indonesia, (Jakarta: Tintamas, 1974), 44. Lihat Juga, Harry J. Benda, Bulan Sabit dan Matahari Terbit, terj. Daniel Dhakidae, (Jakarta: Pustaka Jaya, 1980).

${ }^{20}$ Imam Talkah dan Abdul Aziz, Gerakan Islam Kontemporer di Indonesia; Sebuah Kajian Awal, dalam Abdul Aziz, dkk, Gerakan Islam Kontemporer, (Jakarta: Pustaka Firdaus, 1994), 6-7.

${ }^{21}$ Istilah Timur Tengah mengarah pada wilayah budaya, jadi tidak mempunyai batas tertentu. Definisi yang umum dipakai yaitu wilayah yang terdiri dari: Bahrain, Siprus, Mesir, Turki, Iran, Irak, Palestina, Yordania, Kuwait, Lebanon, Oman, Qatar, Arab Saudi, Suriah, Uni Emirat Arab, Yaman dan Palestina. Timur Tengah, diakses dari http://id.wikipedia.org/wiki/

${ }^{22}$ Jaringan ulama pada dasarnya memiliki akar kuat dalam tradisi keilmuan Islam, yang sering disebut rihlah 'ilmiyah (perjalanan keilmuan) atau "perjalanan menuntut ilmu." Ini sesuai dengan ajaran Islam yang menganjurkan para penganutnya untuk menuntut ilmu ke bagian dunia manapun (thalab al-ilm). Selain itu, tradisi rihlah 'ilmiah secara historis bermula dari perjalanan keilmuan yang dilakukan oleh para sahabat sepeninggal Nabi untuk mengumpulkan dan merekam hadis, selanjutnya tidak hanya menghasilkan kumpulan hadis Nabi, tetapi juga mendorong terbentuknya semacam "jaringan" sahabat yang terlibat dalam usaha merekam, menghafa dan mencatat hadis. Selanjutnya rihlah 'ilmiyah dikenal sebagai upaya menuntut ilmu dan mengembangkan Islam secara keseluruhan. Oman Fathurrahman, Jaringan Ulama: Pembaharuan dan Rekonsiliasi dalam Tradisi Intelektual Islam di Dunia Melayu-Indonesia, Studia Islamika, Volume 11, No. 2, 2004, 367. 
Tengah khususnya yang ada di Haramain (Makkah dan Madinah) telah berlangsung sejak abad ke XVII dan XVIII dan telah membentuk tradisi besar "Islam Besar" yang oleh Azyumardi Azra disebut sebagai "melting pot" (panci pelebur) dari tradisi-tradisi Islam yang berkembang di berbagai wilayah dunia Islam. Tradisi tersebut kemudian ditransmisikan ke Nusantara oleh beberapa ulama yang menjadi bagian dari jaringan tersebut, yakni Nuruddin al-Raniri, Syekh Yusuf al-Makassari dan Syekh Abdurrauf al-Singkili. ${ }^{23}$ Azra menegaskan diantara gagasan utama dalam "tradisi besar Islam" yang dibawa oleh para ulama MelayuNusantara dari Haramayn adalah tentang pembaharuan (tajdid) ajaran-ajaran Islam, dan rekonsiliasi (islah) atau saling pendekatan (rapprochement) antara ajaran tasawuf dan syariat, yang sebelumnya saling bertentangan bahkan menimbulkan konflik dan ketegangan antara ulama tasawuf dan ulama fikih. ${ }^{24}$

Dengan memahami konteks sosio-politik pelembagaan gerakan-gerakan Islam pada periode awal abad ke-XX, maka perkembangan keagamaan di Indonesia pun dapat di potret dengan memahami kaitan antara kecenderungan puritanisme-revivalisme Islam pada satu sisi, dan moderasi-inklusif pada sisi lain. Puritanisme-revivalisme menguat akibat pengaruh langsung dari paham keagamaan yang di “impor" dari Timur Tengah, khususnya paham Wahabi yang menyerukan kembali kepada dasar-dasar agama sebagaimana dipraktekkan oleh kaum salaf dan memurnikan Islam dari bid'ah, peniruan buta (taklid), dan syirik. Sementara kecenderungan moderat-inklusif ditunjukkan dengna penerimaan terhadap konsep pemurnian agama dari timur tengah, tetapi tidak dilakukan secara rigid, melainkan disesuaikan dengan konteks sosio-kultural bangsa. ${ }^{25}$

Menurut Syarifuddin Jurdi, gerakan-gerakan sosial Islam Indonesia, baik sebelum kemerdekaan maupun setelah kemerdekaan, masih menunjukan adanya kecenderungan puritanisme-revivalis dan moderat-inklusif. Kecenderungan tersebut tampak dalam aktivisme gerakan Islam, baik yang berorientasi sosio-kultural maupun yang bersifat politikstruktural. Dari kecenderungan itu melahirkan tipologi gerakan yang juga bervariasi. Adakalanya aktivis Islam Indonesia dalam konteks politik tertentu mengembangkan sikap politik subtantif-inklusif dan adapula yang bersifat simbolik-ekslusif. Ketika kekuatankekuatan Islam pada dekade 1950-an menuntut diberlakukan aturan hukum yang berdasarkan syariat Islam atau mengajukan teokrasi Islam dalam sistem politik Indonesia, tampak dimensi simbolik-ekslusif. ${ }^{26}$

${ }^{23}$ Syarifuddin Jurdi, Wahdah Islamiyah dan Gerakan Transnasional, (Yogyakarta: LABSOS UIN Sunan Kalijaga, 2012), 1. Lihat Juga Azyumardi Azra, Jaringan Ulama Timur Tengah dan Kepulauan Nusantara Abad XVIII, (Bandung: Mizan, 1994). Deliar Noer, Gerakan Moderen Islam di Indonesia 19001942, (Jakarta: LP3ES, 1994).

${ }^{24}$ Oman Fathurrahman, Jaringan Ulama Timur Tengah........., 372.

${ }^{25}$ Greg Fealey dan Anthony Bubalo, Jejak Kafilah, Pengaruh Radikalisme Timur Tengah di Indonesia, (Bandung: Mizan, 2007), 30-36.

${ }^{26}$ Syarifuddin Jurdi, Wahdah Islamiyah..., hlm. 3. Kalangan Islam politik tetap menuntut Piagam Jakarta (hasil kompromi politik 22 Juni 1945) sebagai jalan tengah, sejak dihapus pada 18 Agustus 1945, tuntutan Piagam Jakarta muncul kembali dalam sidang-sidang Majelis Konstituante 1956 di Bandung, hingga kini masih 
Greg Fealy dan Anthony Bubalo mengemukakan bahwa ada dua hal yang menjadi gamblang ketika mempertimbangkan transmisi ide-ide Islamis dari Timur Tengah ke Indonesia. Pertama, transmisi ide-ide tersebut sebagian besar berlangsung satu arah: dari Timur Tengah ke Indonesia. Adanya asumsi bahwa pemahaman Islam yang benar hanya berasal dari bangsa Arab (Timur Tengah), atau dalam bahasa lain segala sesuatu yang datang dari Arab adalah kebenaran, sehingga orang Arab menganggap Asia Tenggara hanya pinggiran intelektual Islam. Kedua, transmisi Islamisme ke Indonesia memiliki beberapa faktor penarik maupun pendorong. Di satu sisi, banyak Muslim Indonesia aktif menuntut ilmu ke Timur Tengah, baik sebagai pelajar atau mahasiswa yang belajar di sana maupun sebagai konsumen penerbitan dan media elektronik. Di sisi lain, pemerintah organisasi amal dan donor pribadi Timur Tengah dengan giat menyebarluaskan interpretasi mereka tentang Islam di Indonesia, dengan cara membiayai infrastruktur Islami seperti masjid, sekolah, madrasah, mensponsori kunjungan da'i dan penerbitan buku-buku dan jurnal serta menyediakan beasiswa belajar di negeri Arab. ${ }^{27}$

Transformasi gerakan Islam dari orientasi yang serba ideologis-politis seperti tercermin dalam praksis politik dekade 1950-an sampai 1960-an dimana gerakan Islam berusaha mewujudkan suatu sistem politik kenegaraan yang sesuai dengan ajaran Islam, bahkan tuntutan untuk mendirikan negara Islam juga menguat khususnya pada dekade 1950-an, tampaknya kini mengalami pengulangan yang sama dengan menguatnya kekuatan Islam yang bercorak revivalis dalam politik Indonesia. Meski sejak dekade 1970-an tuntutan legal formal Islam dalam politik mengalami pergeseranyang signifikan dengan munculnya istilah "Islam yes, partai Islam no" yang dicetuskan oleh Nurcholis Madjid. ${ }^{28}$ Proses ini terus berlangsung yang ditandai oleh sejumlah kebijakan atau regulasi pemerintah khususnya dalam kaitan dengan proses pembatasan ideologi bagi gerakan sosial politik. Meski pada periode yang sama, kalangan muslim tetap menunjukan sikap kritis dan ideologis mereka khususnya dalam kaitannya dengan persoalan kebijakan yang terkait dengan eksistensi umat Islam.

Tiga organisasi secara khusus menerima dukungan finansial yang signifikan dari Arab Saudi, baik dari pemerintah maupun nonpemerintah: Dewan Dakwah Islamiyah Indonesia (DDII), Jamiat Islam wal-Irsyad (biasanya dikenal Al-Irsyad), dan Persatuan Islam (Persis). DDII didirikan pada 1967 oleh pemimpin partai Masyumi yang dibubarkan. Fokusnya lebih kepada dakwah ketimbang politik praktis. Ketua DDII, Muhammad Natsir, dihormati secara luas dalam lingkaran Wahhabi dan salafi Timur Tengah, dan ia menjadi pintu paling penting

muncul tuntutan tersebut. Hal itu sebagai representasi dari kecenderungan simbolik-ekslusif, meski kalangan Islam mengajukan alasan-alasan rasional dan obyektif untuk meyakinkan kalangan kebangsaan dan non-Islam. Lihat Deliar Noer, Partai-partai Islam di Pentas Nasional, (Bandung: Mizan, 1999).

${ }^{27}$ Greg Fealy dan Anthony Bubalo, Jejak Kafilah.........., 84.

${ }^{28}$ Lihat Muhammad Kamal hasan, Modernisasi Indonesia, Respons Cendekiawan Muslim, (Jakarta: Lingkaran Studi Indonesia, 1987). 
untuk masuknya bantuan dana Saudi yang mengalir ke Indonesia selama 1970-an dan 1980an. Al-Irsyad yang didirikan pada 1913 terutama bergerak dalam bidang pendidikan dan dakwah, dan Persis didirikan pada 1924 sebagai organisasi Muslim modernis. Baik Al-Irsyad maupun Persis memiliki sekolah-sekolah Islam yang sangat menonjol dalam pendidikan Islamis Indonesia. ${ }^{29}$

\section{Penyebaran Ideologi Melalui Pendidikan}

Pada umumnya dunia pendidikan dianggap sebagai suatu kegiatan yang selalu mengandung kebajikan dan dalam banyak hal selalu bersifat netral. Akan tetapi dewasa ini dalam dunia pendidikan, banyak pula yang tidak sadar bahwa mereka sedang terlibat dalam suatu pergumulan ideologi melalui arena pendidikan. Pendidikan menjadi lokus yang menggairahkan karena memang mampu terlibat dalam proses perubahan sosial politik.

Pada umumnya, kurikulum madrasah di Indonesia merupakan kombinasi antara mata pelajaran agama dan umum. Untuk madrasah negeri dan swasta, Departemen Agama telah membuat standar kurikulum. Orientasi ideologi keagamaan yang berkembang di lingkungan madrasah negeri sepenuhnya merujuk kepada rumusan dan kebijkan Departemen Agama. Oleh karena itu, ideologi keagamaan dan tujuan pendidikan yang dirumuskan Departemen Agama merupakan cermin dari kehendak politik pemerintah yang berkuasa.

Kebijakan itu sebenarnya juga berlaku bagi madrasah swasta. Akan tetapi, karena madrasah swasta tidak langsung berada di bawah Departemen Agama, mereka memiliki peluang untuk berkembang sejalan dengan cita-cita yang sejak awal menjadi latar belakang pendiriannya. Ditambah dengan adanya ikatan dengan organisasi sosial keagamaan, maka madrasah swasta berkembang dengan ideologi keagamaan di mana madrasah tersebut bernaung. Materi-materi yang berkaitan dengan ideologi keagamaan terdapat dalam kurikulum madrasah swasta. Materi ke-Muhammadiyahan dijumpai di sekolah Muhammadiyah, demikian pula materi ke-NU-an dan ahl sunnah wal jama'ah ditemukan di sekolah dan madrasah lembaga Ma'arif NU.

Untuk sekolah swasta, ideologi keagamaan seperti sudah menjadi kemestian, mengingat sebagian besar merupakan anak kandung dari organisasi sosial keagamaan. Namun yang perlu diperhatikan adalah semakin menguatnya penyebaran ideologi salafi radikal yang terus dikembangkan lewat pendidikan. Beberapa perbedaan sangat mencolok dalam penyelenggaraan pendidikan dan dikhawatirkan akan mengancam eksistensi daripada tujuan pendidikan nasional itu sendiri.

Berbagai gerakan keagamaan seperti gerakan Salafi memiliki akar gerakan reformis gerakan transnasional seperti Ikhwanul Muslimin dan sebagainya. Di Indonesia, gerakan ini tidak hanya menjadi inspirasi dalam konteks interiorisasi nilai-nilai keagamaan, tetapi juga

${ }^{29}$ Greg Fealy dan Anthony Bubalo, Jejak Kafilah........., 97-98. 
membangun lembaga pendidikan sebagai bentuk kaderisasi dan mengimplementasikan konsep Islam yang komprehensif.

Secara umum ada beberapa varian pesantren atau lembaga pendidikan Islam yang memiliki akar dan hubungan dengan pendidikan modern (pesantren modern), terutama dalam perspektif ideologi keagamaan. Sebagai contohnya, Pondok Pesantren al-Mukmin Ngruki Solo, didirikan oleh alumni pondok modern Gontor. ${ }^{30}$ Demikian juga dengan Pesantren alZaitun di Haurgeulis Indramayu, Jawa Tengah. AS panji Gumilang, pendiri dan pimpinan pesantren adalah alumni Pondok Modern. Ustadz Abdullah Said, pendiri dan pimpinan pesantren Hidayatullah Balikpapan, Kalimantan Timur juga tercatat pernah belajar di Pondok Modern Gontor. Ketiga pesantren ini sangat kontroversial jika dibandingkan dengan pesantren lain. Ba'asyir dengan pesantren Ngruki, dikaitkan dengan radikalisme dan terorisme di Indonesia. Sedangkan AS Panji Gumilang dan pesantren al-Zaitun dikaitkan dengan gerakan DI/TII dan NII (Negara Islam Indonesia). Demikian juga dengan pesantren Hidayatullah yang dikaitkan dengan jaringan Jamaah Islamiyah (JI) Asia Tenggara. ${ }^{31}$

Adapun yang menjadi tren baru dalam dunia pendidikan di Indonesia adalah kemunculan berbagai sekolah Islam terpadu yang dikembangkan oleh generasi muda Islamis yang terinspirasi oleh pemikiran-pemikiran Hasan al-Banna, pendiri Ikhwanul Muslimin, dan ideolog-ideolog Islamis lainnya. Penyebaran ideologi keagamaan tertentu lewat pendidikan telah lama berlangsung, meskipun di satu sisi mengaku turut mencerdaskan kehidupan bangsa, akan tetapi hal ini akan menimbulkan masalah tersendiri dalam konteks harmonisasi masyarakat multikultur Indonesia di sisi lain.

Gerakan Islam fundamental telah menjadi kenyataan empiris yang keberadaanya sudah menggejala sedemikian rupa. Gerakan fundamentalisme ini telah memasuki berbagai sektor kehidupan (bidang pendidikan, ekonomi, sosial dan politik). Dalam bidang pendidikan, mereka memilliki berbagai lembaga pendidikan Islam terpadu yang menyebar hampir di seluruh kabupaten dan kota seluruh Indonesia. Sekolah unggulan terpadu mulai dari Pendidikan Anak Usia Dini (PAUD), pendidikan Taman Kanak-kanak (TK Islam Terpadu), Sekolah Dasar (SD Islam terpadu), bahkan SMP dan SMA Islam Terpadu. ${ }^{32}$

\section{Strategi Transmisi Ideologi Fundamentalisme dalam Pendidikan}

Gerakan keagamaan transnasional di Indonesia terlihat semakin menguat -seperti jamaah Salafi, Hidayatullah dan PKS- serta memiliki banyak anggota dan simpatisan. Dalam upaya melebarkan sayap dakwahnya, gerakan ini berkiprah dalam berbagai sektor kehidupan

${ }^{30}$ Seperti diketahui Ustadz Abu Bakar Ba'asyir pernah mengenyam pendidikan di Pondok Modern Gontor. Ba'asyir juga tercatat pernah aktif di Gerakan Pemuda Islam Indonesia, GPII (1969), Pelajar Islam Indonesia, PII (1960-1963), juga Himpunan Mahasiswa Islam, HMI (1964). Lihat Sabili, No. 16 tahun IX (8 Februari 2002), 38.

${ }^{31}$ Arief Subhan, Lembaga Pendidikan.........., 289.

${ }^{32}$ Nur Syam, Tantangan Multikulturalisme Indonesia, (Yogyakarta: Kanisius, 2009), 129. 
seperti sosial, politik, dan ekonomi. Juga tidak ketinggalan membangun lembaga pendidikan sebagai bentuk kaderisasi dan mengimplementasikan konsep Islam yang komprehensif.

Penyelenggaraan pendidikan yang diprakarsai oleh ormas keagamaan ini tidak terlepas dari ideologi, visi dan misi yang melatarbelakangi gerakan tersebut. Sebuah cita-cita bersama gerakan keagamaan transnasional dalam jangka panjang ditengarai yaitu membentuk masyarakat Islam di bawah sistem pemerintahan yang Islami. Usaha ini diawali dengan pembentukan masyarakat Islam di level grassroots. Dalam bidang politik mengupayakan penerapan syariat Islam, pemberlakuan perda-perda syariat, dalam bidang ekonomi menciptakan sistem ekonomi yang sesuai dengan syariah, dan pembentukan generasi Muslim lewat pendidikan Islam yang maksimal sebagai proses regenerasi.

Menciptakan masyarakat yang mengerti, memahami dan mengaplikasikan nilai-nilai Islam butuh usaha keras. Generasi Islam yang ideal dapat terbentuk dalam kondisi keluarga, lingkungan dan pendidikan yang baik pula. Sehingga proses terbentuknya moralitas generasi tidak dapat dilakukan sepihak saja. Pembinaan harus terus dilakukan baik dalam keluarga, lingkungan masyarakat, maupun lingkungan pendidikan formal. Ketiga wilayah pendidikan ini semestinya saling melengkapi dalam usaha membentuk generasi yang baik.

Menyadari hal tersebut, gerakan keagamaan mendirikan lembaga pendidikan formal, selain membentuk komunitas Islami untuk menegaskan eksistensinya. Aktifitas ini merupakan ekspansi gerakan, ${ }^{33}$ dan dapat dikatakan sebagai upaya kaderisasi lewat pendidikan.

Dalam penyelenggaraan pendidikan, transformasi ideology dapat disisipkan dalam hidden curriculum. Secara umum Hidden curriculum dapat melekat pada hampir semua matapelajaran. Hidden curriculum juga dapat ditransfer pada berbagai rutinitas dan kegiatan ekstrakurikuler, proses ini terjadi begitu bebas tanpa ada pengawasan dari siapapun. Sehingga Hidden curriculum dapat dikatakan sebagai ruh dari proses pembelajaran. Dengan adanya Hidden curriculum ini, sekolah melakukan lebih dari sekedar menyebarkan pengetahuan seperti yang tercantum dalam kurikulum resmi, tetapi juga mengandung pesan yang tersembunyi sesuai dengan tujuan yang ingin dicapai oleh sekolah tertentu.

Secara umum di Sekolah Dasar Islam Terpadu (SDIT), dalam beberapa hal menerapkan pola eksklusif-protektif. Pola ini terlihat dalam menginternalisasikan nilai-nilai yang dianggap sesuai dengan syariat Islam pada kegiatan pembelajaran di sekolah. Baik dalam kegiatan belajar formal maupun kegiatan ekstrakurikulernya. Kegiatan pembelajaran memuat pemahaman yang cenderung fundamentalis juga dapat identifikasikan. ${ }^{34}$

\footnotetext{
${ }^{33}$ Selengkapnya tentang ekspansi Salafi, lihat Noorhaidi Hasan, Laskar Jihad; Islam, Militansi dan Pencarian Identitas Pasca-Orde Baru, (Jakarta: Pustaka LP3ES Indonesia, 2008), 31.

${ }^{34}$ Di beberapa SDIT yang dikelola oleh kelompok Salaf memilih untuk tidak mengajarkan matapelajaran Pendidikan Kewarganegaraan (PKN). Walaupun dalam kurikulum dan jadwal pelajaran tercantum PKN, namun pada kenyataannya matapelajaran itu tidak diajarkan. Jadwal pelajaran PKN diisi dengan hafalan Qur'an atau hafalan hadis. Sikap yang diambil oleh pihak pengelola sekolah yang tidak mengajarkan atau meniadakan matapelajaran KWN merupakan sebuah perlawanan terhadap ideologi Pancasila sekaligus penolakan terhadap
} 
Disamping itu, eksklusifitas terlihat dalam perekrutan tenaga pengajarnya. Di SDIT tertentu, calon guru setidaknya diwajibkan memenuhi beberapa persyaratan seperti; harus mengikuti halaqah dan daurah-daurah, serta berbagai kegiatan lain yang diselenggarakan oleh gerakan yang membawahinya. Begitupun ketika telah mengajar, rutinitas yang berkaitan dengan gerakan tarbiyah harus tetap diutamakan. Jika tidak terpenuhi beberapa hal tersebut, maka secara otomatis tidak akan diterima, atau dikeluarkan jika sudah mengajar.

Adapula di sekolah Islam terpadu lainnya yang menyeleksi calon guru sesuai dengan ideologi dan wawasan keagamaan mereka. Salah satunya yang paling utama adalah seleksi ideologis. Para ustadz/ustadzah baru dapat diterima, setidaknya mereka bermanhaj salaf. Untuk mengetahuinya dapat dilihat dari pakaiannya (secara simbolik mengenakan jalabiyah, sorban dan isbal. Bagi perempuan memakai baju lebar, cadar atau niqab.

Tujuan dari seleksi ketat terhadap calon tenaga pengajar ini karena dipercaya bahwa guru merupakan agen perubahan dan teladan bagi siswa. Prinsip keteladanan dianggap cepat dalam membentuk kepribadian siswa. Sesuai dengan target secara umum yang hendak dicapai oleh lembaga pendidikan adalah menghasilkan siswa yang berakidah dan bermanhaj salaf. Sehingga upaya menuju target tersebut juga berdampak dalam proses perekrutan guru.

Dalam hal seragam sekolah, di beberapa SDIT siswa-siswa diwajibkan untuk mengenakan pakaian seragam sesuai dengan standarisasi ideology kegamaan gerakan yang diusung. Diantaranya adalah menggunakan hijab, di mana anak didik perempuan diharuskan untuk mengenakan cadar atau burqah dengan ukuran yang cukup besar. Sedangkan untuk anak didik laki-laki dibiasakan untuk mengenakan jalabiyah dan memanjangkan jenggot.

Jika dikaitkan dengan gerakan sosial, budaya organisasi atau kelompok diasumsikan sebagai budaya yang mampu mengkonstruksi identitas kolektif pada individu yang bergabung dalam gerakan sosial tersebut. Melalui budaya ini, individu mampu mengkonstruksi kemudian memaknai suatu fakta atau peristiwa yang berlaku sesuai konteks tertentu. Dalam hal ini, framing (pembingkaian) tentu saja berperan dan menjadi faktor yang menentukan dalam partisipasi gerakan sosial. Aspek utama yang diperhatikan dalam framing

\footnotetext{
pluralitas. Kepanikan ini ditutupi dengan penekanan terhadap tauhid. Mengajarkan materi-materi yang memuat ideologi Pancasila sama dengan merusak tauhid. Tauhid tidak hanya penghambaan terhadap Allah semata, melainkan juga mengingkari ilah-ilah lainnya seperti hukum dan ideologi hasil pemikiran manusia (demokrasi, nasionalis, sosialis, pancasila). Sedangkan penolakan terhadap realitas agama yang plural amat berlawanan dengan hakikat kondrat kehidupan itu sendiri. Penolakan ini juga melahirkan potensi konflik sosial, baik internal agama maupun eksternal antar agama. Materi-materi pelajaran yang mengandung unsur nasionalisme sangat minim diberikan pada siswa. Pada matapelajaran Ilmu Pengetahuan Sosial (IPS) misalnya, terdapat materi tentang sejarah pembentukan NKRI. Umumnya guru akan menutupnya dengan refleksi sejarah tentang NKRI "yang sebenarnya" (pembentukan Negara Islam Indonesia) sebagai kontra terhadap kebohongan sejarah yang dikembangkan oleh pemerintah. Di samping itu, tidak ada kegiatan upacara bendera dan lagu-lagu nasional sebagaimana umumnya. Dari proses kegiatan pembelajaran tersebut, secara eksplisit terlihat adanya penolakan terhadap sistem sosial-politik yang diterapkan di Indonesia (demokrasi). Pandangan searah dengan gagasan holistik aktivis gerakan Islam yang fundamentalis bahwa Islam sebagai agama dan syari'at, yang mengatur semua aspek kehidupan. Pandangan demikian berkait erat dengan doktrin bahwa Islam sebagai agama dan kekuasaan (din wa al-daulat). Pandangan seperti ini akan terus disublimasi dalam proses pembelajaran.
} 
adalah proses pembentukan identitas pada individu yang terlibat dalam kelompok, agar individu tersebut dapat berperilaku sejalan dan tidak melenceng dari tema dan tujuan utama. ${ }^{35}$ Dalam konteks gerakan sosial, pembentukan karakter atau identitas merupakan bagian dari collective action frame, menghasilkan suatu identitas kolektif yang tidak hanya memperjelas "siapa kita" dan "siapa mereka." Melainkan juga mengidentifikasi bahwa "kita" berbeda dengan "mereka" serta memberikan energi positif pada anggota lain. Identitas kolektif dapat ditunjukan oleh identitas yang terlihat, seperti nama, narasi, simbol, gaya bahasa, ritual, baju, dan lain-lain.

Pembentukan identitas kolektif ditandai dengan kebijakan dan aturan cenderung eksklusif-protektif terhadap siswa-siswi. Pola eksklusif-protektif yang dikembangkan disini bersumber dari pemahaman agama yang kaku. Mengutip Raimundo Panikkar, salah satu sikap keberagamaan manusia adalah sikap eksklusif. Sikap eksklusif artinya menganggap hanya agamanya yang paling benar sementara agama lain salah. ${ }^{36}$ Komunitas keagamaan yang eksklusif biasanya hanya beranggotakan individu-individu yang satu pikiran. Komunitas ini juga mengatur tingkah laku para aktivitasnya dengan membatasi ikatan-ikatan eksternal mereka, serta menuntut ketundukan pada sebuah model perilaku yang ketat. Semua ini bertujuan untuk membangun komitmen para aktivis dan kesatupaduan komunitas.

Implikasi dari sikap eksklusif yang ditanamkan pada siswa salah satunya yaitu konstruksi berpikir yang membuat jarak dengan orang lain di luar komunitas mereka. Hal ini menimbulkan sikap kaku dan curiga dengan membuat pembedaan siapa kawan dan siapa lawan, siapa Muslim dan siapa non-Muslim. Dengan kata lain, mereka membuat demarkasi subyektif anatara "kita" (minna) dan "mereka" (minhum).

Cara penafsiran seperti itu akan selalu menghasilkan penafsiran yang berpijak pada siapa kawan dan siapa lawan. Akibatnya akan menghasilkan paradigma yang tidak menghargai "yang lain" (the other). Dengan kata lain, orang di luar kelompoknya akan dipertimbangkan sebagai entitas yang berbeda, dan karena itu harus diperlakukan berbeda pula. Selanjutnya mereka juga membuat penegasan tentang konsep "kaum muslimin" dan "kaum kafir," dan dengan tegas membedakan dar al-Islam dan dar al-Harb. Pemahaman seperti ini didasarkan pada monopoli terhadap klaim kebenaran (truth claim) yang menegasikan kebenaran yang lain.

Kenyataan ini menimbulkan implikasi yang luas pada paradigma siswa. Bukan saja pada cara berpikir yang tidak menghargai yang perbedaan, tetapi juga akan dimanifestasikan kedalam perilaku atau tindakan tertentu yang eksklusif. Merasa paling benar sendiri dan tidak toleran terhadap keagamaan dan keragaman orang lain. Bukan hanya kepada mereka yang non-Islam, tetapi juga terhadap individu dan kelompok yang seagama sekalipun.

\footnotetext{
${ }^{35}$ Noorhaidi Hasan, Islam Politik..........,134-136.

${ }^{36}$ Raimundo Panikkar, Dialog Intra Religius, (Yogyakarta: Kanisius, 1994), 18.
} 
Pendidikan yang menutup diri dari realitas multikultural hanya akan menciptakan manusia-manusia dengan perspektif sempit tentang nilai dan moral. Karena sejak dini telah dipenuhi oleh nilai-nilai parsial, sementara nilai-nilai universal samasekali tidak diutamakan. Hasil dari pendidikan semacam ini akan berpotensi menyebabkan konflik dan melibatkan umat beragama, karena sejak dini telah dididik untuk bersikap eksklusif. Hal ini sangat bertentangan dengan tujuan dan prinsip peace education.

\section{Penutup}

Situasi Indonesia saat ini masih dapat dikatakan aman dari konflik horizontal yang berskala besar. Meskipun demikian tidak berarti Indonesia terbebas dari konflik dan kekerasan. Dalam diskursus membangun perdamaian (peace building), situasi ini disebut tahap laten dimana potensi konflik masih ada dan bisa meledak kapan saja, tergantung ketersediaan faktor pemicunya. Salah satu upaya untuk membangun dan mempertahankan kondisi yang damai (peace keeping) adalah dengan menerapkan pendidikan perdamaian dalam proses pendidikan di Indonesia. System pendidikan ini arahkan untuk membentuk generasi yang menghargai keadilan, menghargai sesasesamen menjunjung tinggi prinsipprinsip kemanusiaan sebagai prasyarat untuk terciptanya suasana damai dan harmoni.

Pendidikan perdamaian tidak hanya diperuntukkan pada wilayah konflik. Akan tetapi untuk tetap menjaga perdamaian (peace keeping), pendidikan ini juga seharusnya diterapkan diwilayah lain di Indonesia. Salah satu langkah yang paling strategis adalah mewujudkan pendidikan perdamaian melalui pendidikan multicultural yang diselenggarakan oleh seluruh jenjang dan lembaga pendidikan.

Pendidikan multicultural diupayakan untuk menghargai diri dan orang lain, memperbaiki relasi antara orang-orang dari tradisi kultural yang berbeda. Tujuan yang menyeluruh dari program ini adalah untuk membuat siswa mampu belajar saling menghargai dan menilai diri sendiri dan orang lain; mengapresiasi kesalingkaitan orang-orang dalam masyarakat; mengetahui dan memahami apa yang menjadi milik bersama; dan mengapresiasi bagaimana konflik dapat ditangani dengan cara-cara nirkekerasan.

Berangkat dari kenyataan dalam dunia pendidikan seperti yang telah dipaparkan diatas, para agamawan dari kelompok moderat dituntut untuk lebih peka dalam mengatasi penyebaran ideologi fundamentalisme yang ditengarai sebagai pemicu radikalisme dan terorisme. Pendidikan yang diselenggarakan oleh ormas moderat seperti Muhammadiyah dan NU perlu ditingkatkan lagi.

Kedua ormas ini mungkin merasa cukup mapan dan telah banyak memberikan kontribusi bagi dunia pendidikan di Indonesia, akan tetapi kemapanan ini sekaligus merupakan kelemahan dari kedua ormas ini. Sehingga akan sangat disayangkan jika kemapanan ini dimanfaatkan sebagai kelemahan oleh gerakan transnasional yang memiliki tujuan terselubung didunia pendidikan. NU yang mengembangkan pesantren sebagai pusat pendidikan Islam hendaknya lebih gencar lagi menyuarakan perdamaian perspektif nilai-nilai 
Islam yang universal. Begitu juga dengan Muhammadiyah sudah saatnya membenahi amal usaha pendidikannya, serta menerapkan pendidikan perdamaian seperti yang telah dibahas dalam World Peace Forum pada 2010 lalu. Optimalisasi pendidikan oleh ormas moderat ini merupakan salah satu langkah konkrit untuk mengurangi dan memutus ideologi yang membahayakan keutuhan Negara Kesatuan Republik Indonesia.

Pengembangan pendidikan yang sarat dengan ideologi fundamentalisme dapat menimbulkan sikap eksklusif pada siswa sehingga siswa memiliki paradigma yang sempit dalam memaknai kehidupan yang multikultur, multireligi dan multietnis di Indonesia. Selain itu, diharapkan peran aktif ormas moderat, dalam hal ini Muhammadiyah dan NU untuk dapat meningkatkan mutu pendidikan yang mereka miliki untuk mereduksi ideologi fundamentalisme yang digerakkan oleh gerakan agama transnasional dalam pendidikan.

\section{Daftar Pustaka}

Azra, Azyumardi, Jaringan Ulama Timur Tengah dan Kepulauan Nusantara Abad XVIII, (Bandung: Mizan, 1994).

Arkoun, Mohammed, Membongkar Wacana Hegemonik dalam Islam dan Postmodernisme, Surabaya: Alfikr, 1999.

Baidhawy, Zakiyuddin, Pendidikan Agama Berwawasan Multikultural, Jakarta: Erlangga, 2005.Benda, Harry J, Bulan Sabit dan Matahari Terbit, terj. Daniel Dhakidae, Jakarta: Pustaka Jaya, 1980.

Fathurrahman, Oman, Jaringan Ulama: Pembaharuan dan Rekonsiliasi dalam Tradisi Intelektual Islam di Dunia Melayu-Indonesia, Studia Islamika, Volume 11, No. 2, 2004.

Fountain, Susan, "Peace Education in UNICEF," UNICEF Staff Working Papers Programme Division UNICEF, New York 1999.

Freire, Paulo dkk, Menggugat Pendidikan; Fundamentalisme, Konservatif, Liberal, Anarkis, Yogyakarta: Pustaka Pelajar, 2001.

Fealey, Greg dan Bubalo, Anthony, Jejak Kafilah, Pengaruh Radikalisme Timur Tengah di Indonesia, Bandung: Mizan, 2007.

Jurdi, Syarifuddin, Wahdah Islamiyah dan Gerakan Transnasional, Yogyakarta: LABSOS UIN Sunan Kalijaga, 2012.

Hasan, Muhammad Kamal, Modernisasi Indonesia, Respons Cendekiawan Muslim, Jakarta: Lingkaran Studi Indonesia, 1987.

Hasan, Noorhaidi, Laskar Jihad: Islam, Militansi dan Pencarian Identitas di Indonesia Pasca-Orde Baru, Jakarta: LP3ES, 2008.

------------, Islam Politik di Dunia Kontemporer, Yogyakarta: Suka Press, 2012.

Noer, Deliar, Gerakan Moderen Islam di Indonesia 1900-1942, Jakarta: LP3ES, 1994.

Partanto, Pius A dan al-Bary, M. Dahlan, Kamus Ilmiah Populer, Surabaya: Arkola, 1994. 
TAJDID: Jurnal Pemikiran Keislaman dan Kemanusiaan, Vol. 1 No. 2 Oktober 2017, 200-216

Qodir, Zuly, Gerakan Sosial Islam: Manivesto Kaum Beriman, Yogyakarta: Pustaka Pelajar, 2009.

-------, Sosiologi Agama, Yogyakarta: Pustaka Pelajar, 2011.

Raimundo Panikkar, Dialog Intra Religius, Yogyakarta: Kanisius, 1994.

Subhan, Arief, Lembaga Pendidikan Islam Indonesia abad ke-20: Pergumulan Antara Modernisasi dan Identitas, Jakarta: Kencana, 2012.

Syam, Nur, Tantangan Multikulturalisme Indonesia, Yogyakarta: Kanisius, 2009.

Tompson, John B, Analisis Ideologi: Kritik Wacana Ideologi-Ideologi Dunia, terj. Haqqul Yaqin, Yogyakarta: IRCiSoD, 2003.

Tibi, Bassam, Ancaman Fundamentalisme; Rajutan Islam Politik dan Kekacauan Dunia, Yogyakarta: Tiara Wacana, 2000.

Talkah, Imam dan Aziz, Abdul, "Gerakan Islam Kontemporer di Indonesia; Sebuah Kajian Awal,” dalam Abdul Aziz, dkk, Gerakan Islam Kontemporer, Jakarta: Pustaka Firdaus, 1994. 